\section{Den danske industri- og jernbanesabotage \\ - en replik til Danmark besat. Krig og hverdag 1940-45}

\section{af overinspektor, Ph.d. Henrik Skov Kristensen, Nationalmuseet. Leder af Froslevlejrens \\ Museum}

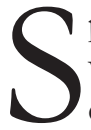
pørgsmålet om, hvordan vi skal vurdere den militære betydning af den danske industri- og jernbanesabotage under besættelsen, har ofte været til debat, såvel i faglitteraturen som i offentligheden. I Danmark Besat. Krig og bverdag 1940-45 (2005) af Claus Bundgård Christensen, Joachim Lund, Niels Wium Olsen og Jakob Sørensen, der har vundet status som et standard-oversigtsværk om dansk besættelsestid, giver forfatterne også et bud på spørgsmålet. Imidlertid forekommer det mig, at forfatterne via fejlslutninger når frem til højst diskutable konklusioner.

Jeg har i flere sammenhænge beskæftiget mig med den militære betydning af sabotage - eller måske mere præcist: hvordan den samtidige vestallierede vurdering af sabotagen var. I det følgende vil jeg derfor sammenfatte de synspunkter, jeg har gjort gxldende.

\section{Industrisabotagen}

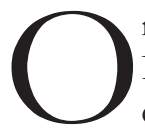
$\mathrm{m}$ det britiske luftangreb mod B\&W den 27. januar 1943 hedder det under kapiteloverskriften "Sabotageangrebet" i Danmark Besat. Krig og hverdag 1940-45:

"Ved at angribe et industri- mål i København understregede man fra britisk side, at den danske industri havde en betydning for den tyske krigsmaskine, og at industrimål som konsekvens deraf var oplagte mål for modstandsbevægelsen. Og angrebet signalerede ydermere tydeligt - og blev også opfattet sådan - at hvis ikke der kom gang i en egentlig industrisabotage, skulle briterne nok angribe industrien fra luften - med den risiko for civile tab, der nødvendigvis følger i kølvandet [...]. $\mathrm{B} \& \mathrm{~W}$-angrebet og SOE's oprustning i Danmark skabte gehør hos modstandsbevægelsen for at iværksætte en hårdere sabotagelinje i Danmark og i højere grad forsøge at rette sabotagen mod industrielle mål. Fra foråret 1943 gik gennemførelsen af sabotage ind $i$ en mere målrettet fase end tidligere, og nu skulle tråden samles op af SOE og modstandsbevægelsen på landjorden."”

Denne udlægning af de britiske motiver bag angrebet på $\mathrm{B} \& \mathrm{~W}$ er imidlertid forkert - og fører uvægerligt til en anden fejlslutning, nemlig den at den danske industrisabotage forhindrede yderligere britiske luftangreb på danske industrivirksomheder.

Jeg har i Vestallierede luftangreb $i$ Danmark under 2. Verdenskrig (som forfatterne til Danmark Besat...da også henviser til, men ikke har læst tilstrækkelig opmærksomt) gjort nøje rede for omstændighederne ved angrebet på B\&W. ${ }^{2}$ Først og fremmest fordi den lange beslutningsgang forud for angrebet afdækker briternes principielle vurdering af danske virksomheders krigsøkonomiske betydning for tysker- 
ne. Her blot nogle centrale nedslag $\mathrm{i}$ denne beslutningsgang.

I det britiske Air Ministry (Luftkrigsministerium) mødtes jævnligt et udvalg, som havde afgørende indflydelse på udvælgelsen af mål for de vestallierede luftvåbnen. I denne "Target Committee" havde alle væsentlige militære og politiske organer sæde, og udvalgets indstillinger kan derfor tages som udtryk for britisk/vestallieret strategi og politik i bredeste forstand.

Fra marts til december 1942 diskuterede udvalget bl.a. mulighederne for at rette luftangreb mod udvalgte industrimål i de tysk-besatte lande (undtagen Frankrig). Den drivende kraft i disse overvejelser var Political Warfare Executive, som bedrev subversiv psykologisk og politisk krigsførelse. I maj 1942 havde Air Intelligence, dvs. det britiske luftvåbens egen efterretningstjeneste, udarbejdet en rapport, som omfattede otte mål: et i Norge, et i Danmark, to i Holland og fire i Belgien. Det "danske" mål var B\&W Diesel i København - det var det eneste "mål af den karakter i Danmark, som kunne komme på tale", som det blev udtrykt i den britiske rapport. Af de otte mål vurderedes i øvrigt kun de to i Holland som lige så vigtige som mål af første prioritet i selve Tyskland.

Endnu i efteråret 1942 var ingen af de otte mål blevet angrebet. På et møde i Target Committee den 4. december 1942 blev et angreb på $\mathrm{B} \& \mathrm{~W}$ igen drøftet. Og nu begyndte en afgørende udvikling. Man diskuterede en efterretningsrapport, som lagde vægt på betydningen af B\&W Diesel. Forman- den for udvalget fremhævede dog, at når vejret var gunstigt for et angreb over København, gjorde det samme sig gældende over primære mål som Kiel og Flensborg. Hertil bemærkede Air Intelligence, at "danskernes åbent fjendtlige holdning over for tyskerne taget $\mathrm{i}$ betragtning, kunne måske selv et lettere angreb forstyrre produktionen på B\&W Diesel." Overvejelserne mundede ud i, at Bomber Command (dvs. Royal Air Forces bombestyrke) skulle undersøge mulighederne for, om der kunne udføres et dagangreb med de lette Mosquitofly - et let "nålestiksangreb", som det hed.

To dage efter dette møde effektueredes det forste af de otte angreb: Philips-fabrikken i Eindhoven i Holland blev angrebet ved en særdeles ambitiøs operation, der på ingen måde kunne betegnes som et "nålestiksangreb". Dette vellykkede angreb blev indgående evalueret på et møde i Target Committee den 18. december, og repræsentanten for Bomber Command tilkendegav, at Mosquito-enheden var stærkt interesseret $i$ at udføre et lignende angreb på et andet mål, der var lige så vigtigt som Philips. Hvad angik B\&W Diesel kunne han dog meddele, at det siden det forrige møde var blevet godtgjort, at dette mål ikke var så vigtigt, at det "kunne retfærdiggøre er større indsats", som han udtrykte det.

At B\&W Diesel ikke i sig selv var et mål af større økonomisk betydning var i mellemtiden blevet bekræftet, da sagen nåede helt op på premierminister Churchills skrivebord. Et parlamentsmedlem havde henledt 


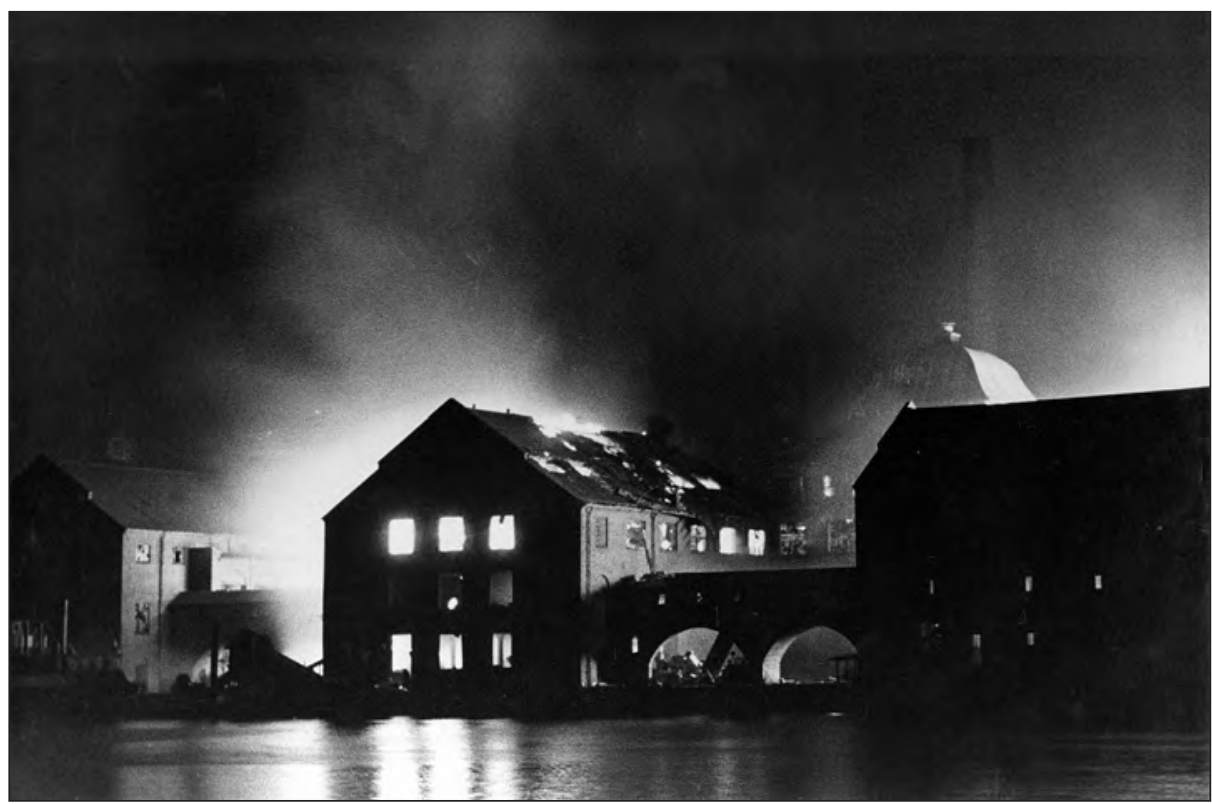

T.v. Alle flybesatninger rapporterede ved hjemkomsten efter angrebet mod B\&W Diesel den 27. januar 1943, at man havde startet en voldsom brand på fabrikken. Det var dog ikke B\&W, som brandte, men Sukkerfabrikken tat ved B\&WW. Angrebet kom fuldstandigt overraskende, og af de 70 ansatte, som arbejdede på aftenskift, blev fire drabt og adskillige alvorligt forbrandt. Fribedsmuseet.

premierministerens opmærksomhed på B\&W, fordi det var et af de "fedeste mål i Europa" på et tidspunkt, hvor briterne betragtede det tyske u-bådsvåben som den alvorligste trussel mod Storbritannien. Churchill indhentede naturligvis en bedømmelse hos Royal Air Forces Luftstab. Den kom den 16. december og beroligede premierministeren med, at B\&W Diesel var, selv om virksomheden hørte til de tolv største producenter af dieselmotorer i Akse-Europa, langt mindre end M.A.N. i Augsburg og Humboldt-Deutz i Køln. Under alle omstændigheder, fremhævede chefen for Luftstaben, så var dieselmotorer ikke en "flaskehals" i den tyske u-bådsproduktion.

Det var således ikke af vægtige økonomiske/militære årsager, at Bomber Commands stab den 31. december 1942 sendte følgende operationsordre til sin Mosquito-enhed:

"For at opmuntre den danske moral er det blevet besluttet at medtage B\&W Diesel på listen over mål, som skal angribes af jeres Mosquitos. I betragtning af danskernes åbent fjendtlige holdning over for tyskerne på nuværende tidspunkt, vil et forholdsvist let angreb, hvor der bliver anvendt tidsindstillede bomber, sandsynligvis hæmme produktionen på anlægget betydeligt. Det er nemlig velkendt, at de loyale danskere er mere end villige til at blive væk fra arbejdet på den mindste foranledning. I skal derfor angribe dette mål ved passende lejlighed, når vejrforholdene 
ikke tillader operationer over Tyskland."

Som nævnt blev angrebet udført (i skumringen) den 27. januar 1943.

På baggrund af ovennævnte

forløb må følgende stå klart: Ingen

dansk virksomhed blev af briterne

anset for at være så vigtig for den tyske krigsproduktion, at man ville bombe den alene på baggrund af økonomisk/militær betydning. Og da slet ikke, når man skulle løbe en risiko for civile tab og deraf følgende risiko for prestigetab i et tysk-besat land. Selv den virksomhed, som man anså for vigtigst i Danmark, B\&W Diesel, kunne "ikke retfærdiggøre nogen større indsats".

For det andet - og det er måske overraskende - bedømte man den danske moral positivt, ja, denne bedømmelse var endda en forudsætning for angrebets gennemførelse.

I Danmark er B\&W-angrebet blevet kendt som "sabotageangrebet" (sådan som det formidles i Danmark besat...) - som angrebet, der skulle tydeliggøre for danskerne, at industrisabotagen var en nødvendighed, såfremt man ville undgå britiske luftangreb på danske virksomheder - med deraf følgende tab af danske liv. Dermed lå en anden slutning snublende nær, nemlig den at den danske industrisabotage (som faktisk tog til efter angrebet mod B\&W) forhindrede yderligere luftangreb på danske virksomheder. ${ }^{3}$

Denne opfattelse kan henføres til, at først og fremmest Ebbe Munck (som var centralt placeret $\mathrm{i}$ Stockholm) omkring årsskiftet 1942-43 gennem SOE-kanaler direkte anmodede London om et britisk luftangreb på enten Riffelsyndikatet eller B\&W, for at få danskerne til at forstå nytten og nødvendigheden af sabotagen. Da så angrebet kom kort efter, syntes årsagssammenhængen indlysende. Sabotagemotivet blev da også godt og grundigt slået fast i den danske bevidsthed, både ved en spontan slutning - og især - ved den illegale presses hurtige og kategoriske sammenkædning af angrebet og manglende dansk sabotage.

Det er da også karakteristisk, at udvekslingen af meddelelser indenfor SOEs danske sektion $i$ tiden efter angrebet er præget af overvejelser vedrørende yderligere luftangreb og sabotage. Her er de stemningsrapporter, som den danske erhvervs- og modstandsmand Erling Foss sendte gennem SOE-kanaler til London en hovedkilde. ${ }^{4}$ Foss' analyser rummer et element, som ligger hinsides kølige militære og økonomiske overvejelser: Han er skamfuld på den danske nations vegne og ønsker, at danskerne bl.a. ved luftangreb skal føle krigens tugt - og opfordrer London til at støtte sabotage mod danske virksomheder, der med Foss' ord tjener "Judaspenge".

Ganske anderledes lidenskabsløst ser man på tingene i London. Her fulgte man også de psykologiske virkninger af $\mathrm{B} \& \mathrm{~W}$-angrebet og var fornøjet derved. Kriteriet for udvælgelsen af stof til Air Ministrys efterretningsoversigter var tydeligvis affødt af selve beslutningsgrundlaget for angrebet: man fokuserede på den passive modstand, man mente angrebet havde afstedkommet i form af arbejdsnedlæggelser mv. Sabotage nævntes ikke med ét ord. 
På baggrund af britiske akter må man konstatere, at danske virksomheders leverancer til tyskerne stak betydeligt mere i øjnene på danske modstandsfolk end på briterne. Og bortset fra B\&W Diesel blev ingen dansk virksomhed udsat for planlagte luftangreb - eller optrådte på Bomber Commands mållister. En og anden vil måske indvende, at Skjern Svineslagteri og Aarhus Oliefabrik blev totalt ødelagt ved britiske luftangreb henholdsvis den 16. april 1941 og den 24. september 1942. ${ }^{5}$ Begge angreb skyldtes imidlertid rene tilfældigheder. Angrebet på Skjern Svineslagteri, som flybesætningen rapporterede var "en fabrik nær Varde", afstedkom ikke desto mindre omfattende luftværnsforanstaltninger på samtlige danske slagterier og mejerier, "da man ikke kunne se bort fra den mulighed, at dette angreb var indledningen på en ny kurs fra britisk side i retning af at ramme den danske levnedsmiddeleksport til Tyskland", som det hed i en vurdering fra Statens Civile Luftværn.

Også angrebet på $\mathrm{B} \& \mathrm{~W}$ gav anledning til nervøsitet: Flere virksomheder vægrede sig efter angrebet ved at fremstille tysk krigsmateriel og henvendte sig til Industrirådet for at få Rådets støtte til at gøre sig fri af tyske leverancer. Fra både B\&Ws og Industrirådets side opnåede man direkte føling med briterne gennem de britiske ambassader i Stockholm og Lissabon. Hovedbudskabet var, at dansk industri arbejdede under "force majeure", og at alle "danske erhvervsfolk ved obstruktion og nedsat arbejdsintensitet var $i$ stand til at forhindre tyskerne $i$ at udnytte det danske produktionsapparat på samme måde, som hvis tyskerne overtog det". Briterne var ikke ukritiske over for denne udlægning (som udover at rummede en kerne af sandhed også var stærkt præget af selektive argumenter), men det må konstateres, at hvad angår den britiske bombepolitik, så blev Danmark betragtet helt på linie med de øvrige tysk-besatte lande. I disse måtte politiske hensyn, dvs. først og fremmest hensynet til civile, jævnligt vige for militære ditto. Denne afvejning blev aldrig aktuel for Danmark, for så vidt angår luftangreb på virksomheder. Man kan ikke deraf automatisk udlede, at den danske industrisabotage ingen krigsøkonomisk betydning havde (udover den politisk/psykologisk mobiliserende betydning den uomtvisteligt havde). Man kan udelukkende udlede, at ingen dansk virksomhed var så vigtig, at briterne ville anvende ressourcer på at angribe den fra luften - samt at den almindelige antagelse om, at den danske industrisabotage forhindrede yderligere luftangreb på dansk industri er højst tvivlsom.

\section{Jernbanesabotagen}

$\mathrm{H}$ vor spørgsmålet om danske virksomheders leverancer til tyskerne således først og fremmest var (og er) et nationalt-mentalt anliggende, som rumsterede i de danske hoveder, så briterne helt anderledes alvorligt på en anden dansk serviceydelse. Denne opfattelse krystaliserer sig tydeligt under den danske modstandsbevægelses henvendelser til London $\mathrm{i}$ sommeren 1943 for at formå de vestal- 


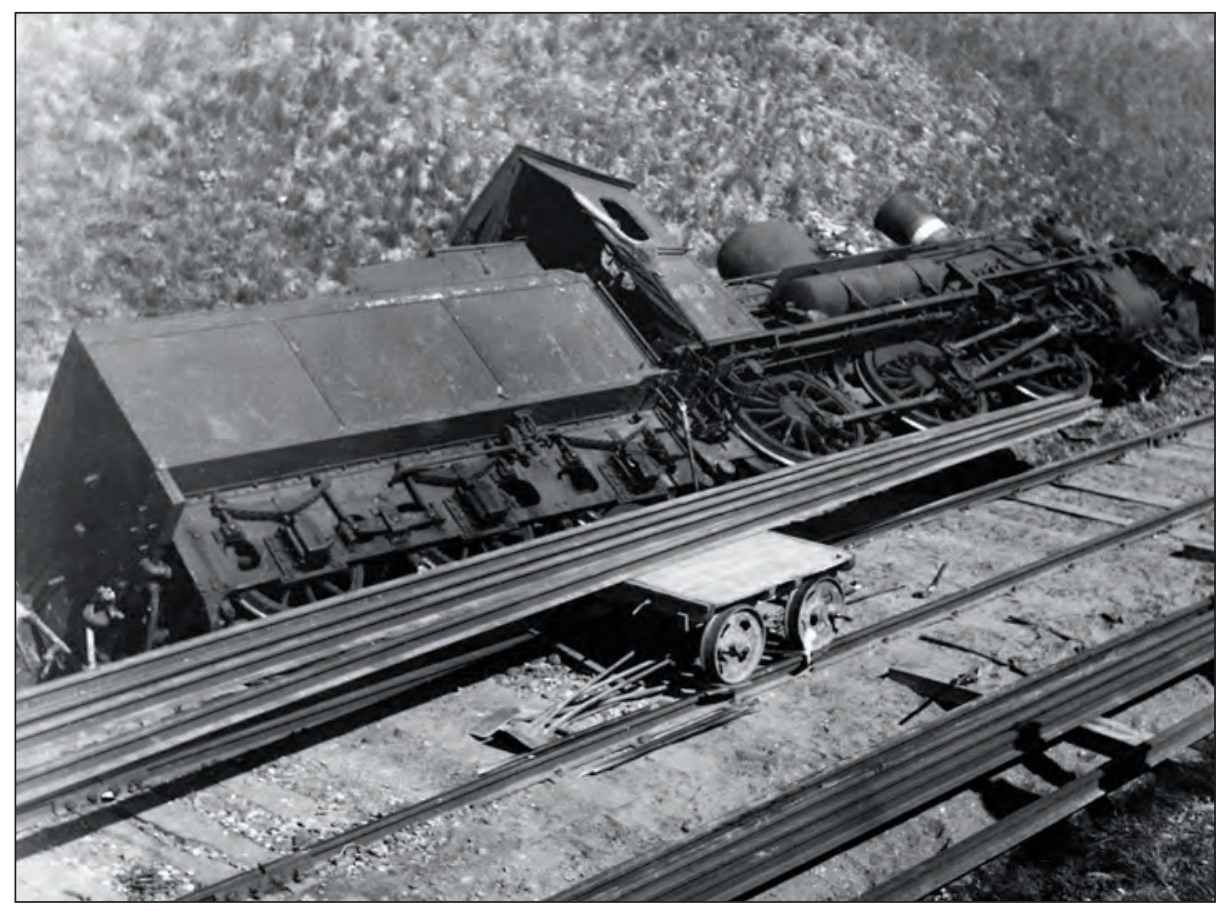

Afsporet lokomotiv ved Lystrup nar Arbus, formodentlig efter en sabotageaktion 18. marts 1945. Fribedsmuseet.

lierede til mere aktivt at understøtte industrisabotagen. I det britiske udenrigsministerium fandt man, at "viljen til at ødelægge fabrikker, som arbejder for tyskerne, er et opmuntrende træk, især da fordi sådanne handlinger ligger fjernt fra dansk mentalitet", men man forstod ikke, hvorfor disse tanker gjorde sig så stærkt gældende i "danske patriotiske kredse". Derimod analyserede man, at "et af Danmarks vigtigste bidrag til den tyske krigsførelse er, at landet bruges som en sikker kommunikationsvej til Norge, og derfor er det soleklart, at enhver sabotage af denne kommunikationsvej hjælper, selv om isolerede sabotageaktioner måske ikke umiddelbart kan synes at have den store virkning". Hermed hentydede man til den danske modvilje mod at iværksætte sabotageaktioner mod jernbaneknudepunkter og færgeforbindelser i 1942 under en britisk offensiv mod de tyske forbindelseslinier, en offensiv som offentligt blev annonceret af luftkrigsminister Sir A. Sinclair og minister for økonomisk krigsførelse Lord Selbourne - de direkte inspiratorer til Christmas Møllers såkaldte "sabotagetale" over BBC i december 1942 (som efterfølgende indbragte Christmas Møller en alvorlig skideballe hos udenrigsminister Eden). I det hele taget mente man i det britiske udenrigsministerium, at danskerne skulle spare på krudtet indtil "Dagen", dvs. indtil de vestallierede landede på det europæiske fastland.

Dette skete som bekendt med 
invasionen i Normandiet den 6. juni 1944, og i forbindelse hermed udstedte de vestallierede "Operationsbefaling nr. 1 " til den danske modstandsbevægelse - en befaling som satte de tyske troppetransporter til og fra Danmark øverst på listen over mål.

I de følgende 25 år stod det uantastet, at den danske modstandsbevægelse gennem omfattende jernbanesabotage i krigens sidste måneder ydede et værdifuldt militært bidrag til den vestallierede krigsførelse i direkte samarbejde med SHAEF, overkommandoen for de vestallierede styrker på Kontinentet - lige indtil historikeren Aage Trommer i sin kontroversielle disputats fra 1971 underkastede den danske jernbanesabotage en grundig analyse.

Trommers arbejde er uomgængeligt, og enhver, der vil beskæftige sig seriøst med jernbanesabotagen, må forholde sig til hans resultater. Derfor følgende lille ekskurs, inden jeg vender tilbage til Danmark besat..., hvis forfattere grundlæggende accepterer Trommers konklusioner og præmisser.

Primært med baggrund i DSB-akter kunne Trommer påvise, at den danske jernbanesabotage kun havde medført minimale forsinkelser, som havde ringe eller måske slet ingen indflydelse på de militære begivenheder længere sydpå. Eller som Trommer (myteknusende) formulerer det i sit forord:

"Da jeg begyndte arbejdet med at konfrontere sabotageindsatsen på jernbanerne med den tyske trafik, skete det ud fra en forventning om, at jeg på en eller anden måde ville nå frem til en konstatering af, hvor meget jernbanesabotagen havde betydet, hvor stor dens virkning havde været. Det var med overraskelse, for ikke at sige forbløffelse, at jeg, efterhånden som arbejdet skred frem, måtte erkende, at konfrontationen ubønhørligt tvang mig ud i en påvisning, der er bogens hovedtese: hvor lidt jernbanesabotagen havde været i stand til at influere på det militære begivenhedsforløb i den danske afkrog af Den anden Verdenskrig.",

Trommer pegede endvidere på, at kildegrundlaget for den hidtidige opfattelse var højst problematisk: det drejede sig dels om modstandsbevægelsens eget materiale, primært i form af aktørberetninger, dels om synspunkter med proveniens i SOE, som fra London koordinerede den danske jernbanesabotage. Begge måtte i sagens natur have en meget positiv opfattelse af sabotagens effekt.

Fra vestallieret professionel, militcer side, pegede Trommer på, var materialet derimod særdeles sparsomt. Eneste tilkendegivelse forelå i en form, som meget vel kunne tolkes som blot en gestus overfor den danske modstandsbevægelse, eller som Trommer udtrykket det "smukke ord": Den 5. marts 1945 udsendte SHAEF (offentligt) et særkommuniké, som understregede den danske jernbanesabotages store betydning for de igangværende allierede militære operationer.

Jeg skal ikke på nogen måde anfægte Trommers hovedtese, nemlig den at den danske jernbanesabotage kun medførte ringe forsinkelser af de tyske troppetransporter, derimod kan der være 
grund til at kaste lys over den vestallierede opfattelse af den danske jernbanesabotage, og hvilken betydning denne opfattelse kan have haft. ${ }^{7}$

Selv om Trommer i sin afhandling konkluderer, at "de to nordiske lande ikke havde afgørende betydning som troppereservoir for tyskerne", og at "tilskuddet herfra aldrig var af afgørende betydning" for kampene på Kontinentet, ja, så må man på grundlag af vestallierede militære akter fastslå, at de vestallierede dels fulgte transporterne meget nøje, dels investerede betydelige militære ressourcer $\mathrm{i}$ at hæmme dem. Ikke mindst efter den finsk-sovjetrussiske våbenstilstand den 19. september 1944, som betød, at 200.000 kampvante tyske tropper fra 20. Gebirgsarmee gradvist blev overført fra den nordlige østfront til Nordnorge. Herfra blev de overført til det europæiske fastland for at afstive den vaklende tyske front. Overførslen skete via Oslo, hvorfra tropperne blev sejlet til hovedsageligt Århus. Fra Århus blev tropperne transporteret videre sydpå med tog ned gennem Jylland.

Den vestallierede interesse for kommunikationen over Danmark skærpedes i øvrigt yderligere af, at man vurderede, at Norge på dette sene tidspunkt af krigen var den tyske krigsindustris sidste kilde til råvarer.

Her blot et enkelt aktstykke til at illustrere den vestallierede opfattelse. I en efterretningsoversigt for marts 1945 udarbejdet af Royal Air Forces' Coastal Command (Kystkommando) hedder det bl.a.:

"Fint vejr har tilladt luftan- greb næsten hver nat på skibsfarten i transit fra Oslofjorden til Danmark. Genopstillingen af fjendens skibe, tropper og materiel, som har afgørende betydning for begivenhederne på både vest- og østfronten, gør denne trafik særlig vigtig for nuværende”.

Coastal Command, som var en af tre operative kommandoer under Royal Air Force, udførte i tæt samarbejde med bl.a. det britiske Admiralitet en veritabel offensiv mod skibstrafikken mellem Tyskland og Norge fra efteråret 1944. En anden af det britiske luftvåbens kommandoer, Bomber Command, bidrog til offensiven ved at intensivere en i forvejen særdeles omfattende minelægning i de samme farvande. De danske farvande og farvandene omkring Danmark hørte til de mest intensivt minerede under 2. Verdenskrig.

Royal Air Forces' tredje kommando, Fighter Command, blev også inddraget $i$ offensiven, da Coastal Commands fly i marts 1945 udover natlige angreb tillige indledte dagangreb mod skibstrafikken. Jagerflyenes opgave var af eskortemæssig karakter.

For de vestallierede var der imidlertid endnu en faktor, som bidrog til offensiven: den danske sabotage af jernbanenettet i Jylland. Dette fremgår af flere samtidige, interne militære analyser bl.a. i Coastal Command. Klarest kommer det til udtryk i en analyse udarbejdet på højt niveau i SHAEFs efterretningsdivision. Papiret, som har karakter af et mindre internt og klassificeret memorandum dateret den 4. april 1945 (og dermed som kilde betragtet af en helt anden kvalitet end et kom- 
muniké), er stilet til SHAEFs operative ledelse, og følgende uddrag giver indtryk af papirets vurderinger:

"Som et resultat af minelægning og luftangreb på skibsfarten i farvandet mellem Norge og Danmark og af omfattende sabotage mod jernbanerne i begge lande inden for de seneste tre måneder er overførslen af tropper fra Norge til Tyskland blevet betydeligt hæmmet. [...]

Sabotørernes angreb mod jernbanerne har forsinket troppernes ankomst til indskibningshavnene i Norge og især deres videre transport efter ankomsten til danske havne. [...]

Der er ingen tvivl om, at den samlede offensiv bestående af minelægning, luftangreb og sabotage, som blev iværksat i december, har vist sig utrolig effektiv mht. at hæmme overførslen af tropper fra Norge. Derved er fjenden blevet forhindret $\mathrm{i}$ at benytte disse tropper på det europæiske fastland i en altafgørende fase af krigen. [...]"

På baggrund af bl.a. dette papir må det være nærliggende at konkludere, at SHAEF's hyldest-kommuniké i marts 1945, var andet end blot en gestus - at SHAEF og andre vestallierede, militære instanser rent faktisk vurderede den danske jernbanesabotage som en væsentlig militær faktor - hvor fejlagtig vurderingen end måtte være.

Kunne det tænkes, at denne vurdering forhindrede vestallierede luftangreb på jernbanemål i Jylland fra omkring årsskiftet 1944-45? Som Trommer anfører i sin disputats, må jernbanesabotagen "ligesom andre former for sabotage principielt ligestilles med luft- krigsførelsen som taktisk kampmiddel. De to kampformer supplerede hinanden og sigtede mod samme mål".

Hvis det er tilfældet, har den danske jernbanesabotage altså dog "haft indflydelse på det militære begivenhedsforløb i den danske afkrog af Den anden Verdenskrig" - selv om Trommers grundige undersøgelse påviser dens begrænsede taktiske effekt.

Nu er én ting jo, hvad forskningen efterfølgende kan fastslå. Noget andet er det beslutningsgrundlag, som aktørerne i samtiden har haft til rådighed og har været nødt til at handle ud fra. Den anden (eller rettere tredje) samtidige aktør, tyskerne, synes også at have tillagt jernbanesabotagen betydning, om end kildematerialet til at belyse den tyske opfattelse er sparsomt.

Om tyskerne så har følt jernbanesabotagen som en alvorlig belastning eller blot som et irritationsmoment, ved vi mindre om. Men at de har måttet tage den i betragtning $\mathrm{i}$ deres planlægning, genspejles i de tyske akter. Den 6. februar 1945 indløb en telefonisk besked fra Førerhovedkvarteret i Berlin til den øverstkommanderende for de tyske tropper i Danmark, Generaloberst Lindemann: 'Føreren forventer, at yderligere sabotageanslag mod troppetransporter vil blive bekæmpet med alle midler”. Og to dage efter gjorde Lindemann de tyske kommandører personligt

T.h. Memorandum fra den 4. april 1945, som frembaver den danske jernbanesabotage som en vasentlig militar faktor $i$ den samlede offensiv mod de tyske troppetransporter fra Norge. Public Record Office, London. 


\section{TOP SECRET

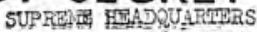 \\ ATI IZD FXPNDIIII OTARY FORGE \\ Offico of. Assistant ehief of Staff, a-e \\ TORWARD HEADQLARTERSS}

$C B I / O I-3 / 370,5-3$

4 April 194

Subjecti Wovement of German Troops from WORLAY.

To:

A, C. of $S, G-3$. (Copy No.1)

1. As a result of sea mining and air attacks on shipping in the vators between NORWAY and DENIIIRK, and of extensive and persistent sebotage at tacks against rallways in bòth countrios which have taken place in the last three months the movement of troops from NORMIY to GERilurY has been greatly intefered with. Whereas in Decenber shipping vas arriving in DEMiA: at a rate of some 80,000 tons per week or the equivalont of 2 - 3 divisions a month; the rate has Eradually dropped to less than 10,000 tons in the weok 24 - 31 karch. This despite the faot that it is known that the onemy is anxious to conitinue the withdrawal of troops from KORlity as rapldy as possi

2. In adaition the onery has in the last three months been donled the use of some 65,000 tons of shipping either sunk or tomporarily put out of commission by damago. In viow of the recont 5 reatly increased nocd for shipplng in the Sastern BirTIC, and ospocially the noed for guitable troopships, throe large and sevoral small vossals have recently had to be transfo from the Westem to the Fastern BiLIIC, Such transfers and Iosses imposo on the enemy the neod to produce replacomonts if the volume of movoment from NQRWAY is to bo malntained. These losses iave not beonfully roplaced as yo and havo apparently forcod tho eneny to soizo 15 Danish ships,

3. Attacls on railways by saboteurs has in addition slowed down tho rate of arrival of troops at ombarkation ports in MORWYY and more ogpocially the moveraent awny aftor arrival at Danish ports.

4.

There is no douot that tho programo of nining, air attacks, and sabotage initicted in Dooomor has proved oxtromoly succossful in sloving down the rato of movomont of troops from NORHAY. As a rosult tho onemy has been doniod tho uso in EuROPI of much noodod troops at a most vital poriod of tho war.

5. It is know that the oneny is vigorously attompting, by soizing Danish shipping and comissioning vossols hithorto lald up, to rastore tho high rato of troop movomonts from Scandinovia whoro at leat socio 7 division are still availavlo for export and aro badly neodod in EUROPE. Al though unlikoly now undor any circunstances to arivo in time to influcnco tho nain battlo theso forcos could still exarciso en frportant nulsanco value vore th availablo to wan fortrossos in tho north Juropoan ports, It is cloar thorofore this the prosont serios of attacks should be naintained.

6. It is suggostod thet tho succoss attrinod by attacks carriod out in tho last throo nonths bo mado known to tho air and specinl forcos concom and the inpertenco of continuing the activities for the present, dospito rocont alliod succossos, be pointod out.

Copies to:

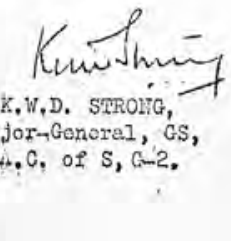


ansvarlige for, at troppetransporterne forløb uden forsinkelser.

Det nærmeste, vi kommer en egentlig vurdering af jernbanesabotagens effekt, er en kort melding fra den 14. april 1945 fra Marineoverkommando Øst i Kiel til chefen for den tyske Krigsmarine i Danmark, admiral Wurmbach. På baggrund af de forstærkede luftangreb i Skagerrak og Kattegat, samt de kortere nætter, ønskede man, at Wurmbach skulle prøve, om det var muligt at lade hurtige troppetransporter anløbe Frederikshavn i stedet for Århus (og dermed længere jernbanetransport ned gennem Jylland). Og man fortsatte: "Vanskeligheder i forbindelse med jernbanetransport er velkendte, men de må overvindes. Der henvises til hæren, som foretrækker selv store forsinkelser gennem længere jernbanetransport frem for total tab til søs. Meld hvilke jernbaneforsinkelser der opstår ved at anløbe og udskibe i Frederikshavn".

Wurmbachs eventuelle svar kender vi ikke, men den tyske vurdering viser, at nok var jernbanetransporten forbundet med gener pga. sabotagen, men de var at foretrække for tabene til søs forårsaget af luftangreb og miner.

Hvorom alting er: der er kildebelæg for at hævde, at de samtidige aktører betragtede jernbanesabotagen som en militær faktor - og at man inddrog den i sin militære planlægning. Det forekommer derfor problematisk (og dybest set at være udtryk for en ahistorisk tilgang) at opretholde det synspunkt, at jernbanesabotagen ingen betydning havde for de militære begivenheder $i$ Danmark samt at frakende den enhver militær betydning.

Dette gør forfatterne til Danmark Besat. Krig og hverdag 1940-45 da heller ikke, idet de (især under henvisning til SHAEFs memorandum af 4. april 1945) anerkender, at de vestallierede, professionelle, militærfolks vurdering 8 er "betydningsfuld, selvom den ikke er korrekt". For dem består det betydningsfulde $\operatorname{dog} i$, at "Aktionerne var medvirkende til, at Danmark i den sidste fase af verdenskrigen blev opfattet som en nation, hvis tætte bånd til Tyskland var ufrivillige. I den henseende betød det ikke så meget, hvad effekten var." Dermed abstraherer forfatterne dog fra det militære til det politiske niveau og viger i realiteten uden om det spørgsmål, som Trommer i sin tid stillede - og som han mente at kunne svare benægtende på: "Havde jernbanesabotagen nogen indflydelse på det militære begivenhedsforløb i den danske afkrog af Den anden Verdenskrig?"

Jeg mener, den i en vis forstand havde - ganske enkelt fordi de samtidige aktører tillagde den betydning. Og for briternes vedkommende især fordi de forventede, den ville have betydning.

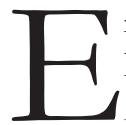

n sammenfatning af min kritik kunne være, at forfatterne til Danmark besat... hævder, at der er en sammenhæn mellem fravær af luftangreb og (industri)sabotage, hvor sammenhængen ikke findes, og overser sammenhængen mellem (jernbane)sabotage og fravær af luftangreb der, hvor sammenhængen sagtens kan være. 


\section{Noter}

1 Claus Bundgård Christensen m.fl. 2005. s. 381.

2 Henrik Skov Kristensen, Claus Kofoed og Frank Weber: Vestallierede luftangreb i Danmark under 2. Verdenskrig bd. 1-2, 1988, bd. 1 s. $371-412$.

3 Denne fortolkning blev første gang formidlet og kildebelagt i en videnskabelig sammenhæng af Jørgen Hæstrup i Kontakt med England fra 1954. Siden har fortolkningen været helt central i bedømmelsen af dels den danske industris betydning for den tyske krigsøkonomi, dels af betydningen af den danske industrisabotage.

4 Stemningsrapporterne blev i 1946 publiceret i Erling Foss Fra passiv til aktiv modstand.

5 De to angreb er analyseret og beskrevet i Henrik Skov Kristensen m.fl. 1988, bd. 1. s. 207-210 og s. 293-297.

6 Aage Trommer Jernbanesabotagen i Danmark 1971. Trommer har i Disse fem år fra 2001 i sammentrængt form repeteret sine synspunkter på jernbanesabotagen.
7 Jeg har i Henrik Skov Kristensen m.fl. 1988 bd. 2, s. 665-669 berørt den danske jernbanesabotage i kapitlet "Strategiske og taktiske mål i Danmark - luftangreb og sabotage som alternative kampmidler". Uddybende og med stillingtagen til Trommers tese, se min artikel "Jernbanesabotagen - havde den militær betydning?" i Historie 19, 1, 1991, s. 92-100 (med kort replik af Aage Trommer). Desuden mine artikler "Jernbanesabotagen i Sønderjylland" i Axel Johnsen og Birgitte Thomsen (red.) 19 myter i Sonderjyllands historie, s. 241153 og "Luftkrigen og Århus" i Henrik Fode (red.) Arbus besat, 2005, s. 80-110. Senest har jeg gjort rede for mit synspunkt i "Jernbanesabotage og og ventegrupper" i Henrik Lundbak (red.) Sparretid. Hverdag under besattelsen 1940-45, 2006 (2. udgave) s. 200-203.

8 Dette gøres under henvisning til Henrik Skov Kristensen 1991.

9 Bundgård Christensen m.fl. 2005, s. 541. 